\title{
Analyzing Interpersonal Metafunction through Mood and Modality in Kaine Agary's Yellow-Yellow from Critical Discourse and Womanist Perspective
}

\author{
Léonard A. Koussouhon ${ }^{1} \&$ Ashani M. Dossoumou ${ }^{1}$ \\ ${ }^{1}$ University of Abomey-Calavi, (UAC), Abomey-Calavi, Bénin \\ Correspondence: Ashani M. Dossoumou, Department of English Studies, Faculty of Arts and Humanities \\ (FLASH), Laboratory for Research in Linguistics and Literature (LabReLL), University of Abomey-Calavi, \\ (UAC), Abomey-Calavi, Bénin. E-mail: dossoumoumichel@gmail.com
}

\author{
Received: October 24, 2015 Accepted: November 10, 2015 Online Published: November 30, 2015 \\ doi:10.5539/ijel.v5n6p20 URL: http://dx.doi.org/10.5539/ijel.v5n6p20
}

\begin{abstract}
The aim of this paper is to analyze mood, epistemic and deontic modality patterns in an extract culled from Yellow-Yellow (2006) by one of the Nigerian new millennium female writer, Kaine Agary. The findings data revealed by the interpersonal meaning analysis are discussed against the backdrop of critical discourse analysis and womanist theory. The discussion contended that, despite the blend of monologic and dialogic organization of the novel, Kaine Agary has tried to portray the sociological schisms making up the daily life of young girls in the oil-resourced region of Nigeria. More importantly, the authoress has shown women's determination and commitment to support Zilayefa to succeed in achieving good results in education while the major male character goes against this developmental stream flow by impregnating her. The mood and modality choices operated show some kind of power and hierarchy relations and conflicting ideologies between Sisi, Lolo, Zilayefa and Admiral. The discursive interpretation eventually found out that the interpersonal meaning description and critical discussion can properly work together towards achieving consensus. It is agreed that the hidden authorial ideology behind Kaine Agary's fictional text is geared towards a pro-women social change for a more balanced African society. This is, of course, the gist priorities and great topical issues calling for urgent response at this time.
\end{abstract}

Keywords: mood, modality, deontic, epistemic, commitment, ideologies

\section{Introduction}

The new trend in African fiction is being more and more focused on women social emancipation and empowerment. Among the sectors fostering and legitimizing this vital societal ambition, range education and schooling that heal the wounds of ignorance, mainly for the young girls. Many gender mainstreaming advocacy policies being developed in this regard in Africa including the community-based girls care and protection that is one of the cornerstones portrayed in Kaine Agary's Yellow-Yellow (2006). This novel set in the Niger Delta, township of Port Harcourt, paints sociocultural and power relations among women, and between women and men impersonated in characters like Sisi, Lolo, Zilayefa and Admiral.

This article is premised on the exploration of the grammar of interpersonal meaning by focusing on mood choices, deontic and epistemic modality patterns. In the process, it analyzes an extract culled from the novel under study, discusses the findings data against the dual backdrop of critical discourse analysis (CDA) and womanist theory in order to underscore the social change ideology embedded therein. The study applies the qualitative research paradigm method by critically and systematically selecting an extract for analysis and mainly by drawing on research studies so far carried out in the field. The revealed findings are screened, disaggregated, summarized and tabulated. Under the CDA and womanist theory lenses the social change projector will shed more light on the Sisi and Lolo's sustained determination to foster women emancipation and empowerment through Zilayefa's education and social welfare. The modulated interrogative mood along with some epistemic and deontic modality choices will reveal the other side of the medal painted in the same fiction through Admiral- the lionized male character who has used his political and economic power to influence and impregnate the young girl who entirely bit the bait and got caught in the love trap. 


\section{Methodology and Literature Review}

As part of this study, the data collection process has been carried out in line with the qualitative research paradigm. It has consisted in selecting systematically an extract from the novel under study, namely Kaine Agary's Yellow-Yellow (2006). Then the extract has been analyzed according to the principles guiding the grammar of interpersonal meaning focusing on its constituents of Mood/Residue components broken down into subject, finite, non-finite, predicator, complement, adjunct, and modality (deontic \& epistemic) (Fontaine, 2013). The data gathered from the analysis have been screened, disaggregated, processed, and tabulated according to their typologies. For the purposes of findings discussion, this article considers in a continuum mood and modality choices, (Ayoola (2013); Koussouhon \& Dossoumou (2015); Koussouhon, L \& Koukpossi, (2013); Taiwo (2014) and Akogbeto \& Koukpossi (2015)). Drawing on these two salient linguistic devices, and reasoning against the backdrop of the principles guiding the CDA and the womanist theory to text/discourse, the discussion culminated with the identification of the authorial ideologies, values and ideals that guided the crafting and writing of the novel under study.

Indeed, this work is far from being a pioneering one because so many scholars have done much so far in this field. However, this paper goes about the exploration of the internal system that language represents through the potential meanings encoded in Kaine Agary's fictional texts/discourses. Among the previous works in the field, range those abridged and summarized below.

Amoussou (2015) investigated Abiku by pairing and comparing its treatment by Soyinka and Clark through poetry. His analysis came up with the mind that the contexts of situation and of culture have not been enough to explain the differences neither between Soyinka and Clark's treatments of Abiku, nor between their tenors of discourse. Identifying the many similarities between the two poems, he observed and highlighted that both authors have nearly the same contexts of situation and of culture (a Nigerian/Yoruba issue discussed in the English language). Though they differ in their ideological perceptions to Abiku, the two poets do share many similarities. Clark regards Abiku as a mere evil child and thus can be talked to in an authoritarian tone and abused without apology while Soyinka, drawing on his Yoruba cultural background considers Abiku, not just as a mere child, but mainly as an ancestor, an elder, a palmist full of knowledge and therefore worthy of respect. In short, while Clark seems to give just a shallow societal treatment, or interpretation to the concept of Abiku, Soyinka rather enshrines in the concept a deep meta-societal, mystical, metaphysical or even philosophical interpretation. Abiku's authoritarian tone is the assertion of his will power and correction of the parents' view of him.

Koussouhon \& Dossoumou (2015) have shed the systemic functional grammar projector's light on how Helon Habila encoded journalistic experience through meanings to create, adopt and manage a gender-balanced and womanist perspective in the novel Oil on Water (2012). Focusing on ideational metafunction for the redefinition and re-presentation of African women's personality, ability and identity, they have placed the Nigerian new millennium writer in a good position to reconstruct the African woman's past and present in proper perspectives to project the future of her image. They have concluded that the author moves to sustaining and advancing the literary orientation geared by the fictional movement of redefinition, reshaping, restoration, and re-presentation of African women's personality, ability and identity.

Ayoola (2013), in his study has attempted to present interpersonal analysis of political advertisements. The analysis revealed that there is no one-to-one correspondence between the lexico-grammar and interpersonal meaning of a clause. The study has also revealed that the attitude and opinion of the speakers in the political adverts are covertly indicated neither by the use of modal verbal operators nor mood adjuncts but by the lexical choices as well as grammatical structures that reflect the socio-economic and political context of the adverts. Besides, the study has shown that the interpersonal meaning of a structural choice is not determined by the lexico-grammar but rather by contextual factors. Eventually, he has concluded that the analysis done in his study would enhance better understanding of political advertisements from interpersonal metafunction perspective.

Investigating the ideologies underpinning Obama's victory and inaugural addresses, Ye (2010) focused only on interpersonal metafunction analysis to identify some ideological key components, namely Pragmatism, liberalism, inclusiveness, acceptance of religious and ethnic diversity and unity embedded therein. The analysis revealed that the speech is dominated by positive declarative and imperative. Modal operators like will, can and must are highly used. The first person pronouns turned out mostly in the speech followed by second person pronoun you, encoding his political commitment and accountability as well as the American people's supportive inclusiveness. 
Akogbeto \& Koukpossi (2015) have explored gender issues in Wole Soyinka's The Lion and the Jewel from systemic functional linguistics and critical discourse analysis perspective. The results of their investigation under the dual lens and projector of transitivity and critical discourse analysis prompted them to conclude that Soyinka, consciously or unconsciously has portrayed lionized-male characters as the symbol of strength, and irresistible power. Moreover, it can be inferred from their findings that transitivity patterns analysis has allowed them to shed light on how characters construe their experiences through language use. As such, the material, mental and relational processes' depiction has significantly contributed to deliver such an objective. While male characters are portrayed as initiator, doer, commander-in-chief of actions, female characters are portrayed as goals and beneficiaries of male-performed actions. More importantly, their exploration allowed them to observe that female characters are associated in the novel with processes of sensing and emotion before coming up with the conclusion that women are emotional beings.

Working on François Hollande's inaugural speech, Koussouhon, L \& Koukpossi, (2013) have pointed out that the systemic functional linguistics is a field of much attention in Anglophone universities and in the English studies departments of some French-speaking countries. The application of this theory to the Inaugural speech of François Hollande, focusing on material, relational, and mental processes and the participants has revealed that most of the processes in this speech are material. This outnumbering material processes, according to them denotes a strong political commitment for strategic situations and concrete actions.

In a move to critically analyze the use of modal auxiliaries in Nigerian political manifestos, Taiwo (2014) has emphasized on their ideological use by Nigerian politicians especially in their electioneering campaign manifestoes; those policy documents that are designed in order to elicit favourable political support from the electorate. The study revealed that modal auxiliaries such as 'will', 'shall', 'must', 'can', etc. are used by the politicians in two manifestoes for persuasion, obligation, to make promises, demonstrate political will/commitment, and solicit public support and manipulation. He concluded that his study averred that modals are not just linguistic elements, but most importantly, political devices and ideological tools in political discourses. They are used to accentuate specific aims and themes in Nigerian political rhetoric.

Based on the theory of new rhetoric and CDA, Zhou and Kazemian (2015) have made a systematic investigation into the rhetorical process of English political public speaking (EPPS) to figure out how speakers achieve its rhetorical effect. In the same vein, they have discussed how the politicians use identification strategies to transcend division, gain identification, induce cooperation, and thus, realize their motives. In order to guide their investigation, they have considered that a rhetorical model of EPPS identification is put forward to help people interpret EPPS in a more effective way. They have concluded that firstly, the rhetoric of EPPS is a process of identification in which both the speaker and the audience try to commune with each other, verbally and non-verbally, in content and in form. Secondly, some identification strategies are used more frequently than others in EPPS, according to different circumstances under which EPPS has been delivered and based on the various purposes the speakers intend to achieve. Thirdly, an EPPS is always well-prepared rather than impromptu. Fourthly, EPPS always has clear and logical reasoning, emotional expressions. Moreover, the speaker always employs repetitive form to help the audience remember the theme of EPPS.

In much different veins at recent annals of literature, some other considerable studies have also been conducted in SFL, Rhetoric and CDA, carrying out a lexico-grammatical and semantic investigation of various texts and discourses. This investigation has aimed at discerning the multiple strategies exploited by orators and authors in political, scientific, religious etc. texts to make their discourses persuasive, significant, appealing and obscure as well (Cap \& Okulska, 2013; Kazemian et al., 2013; Kazemian \& Hashemi, 2014a, b; Noor et al., 2015 a, b; Ali \& Kazemian, 2015; Ali et al., 2015; Nur, 2015).

Previous studies have tended to concentrate on some other genres and discourses. This study is unique in the sense that it attempts to bridge the gap among previous studies by Analyzing Interpersonal Metafunction through Mood and Modality in Kaine Agary's Yellow-Yellow from Critical Discourse and Womanist Perspective. Indeed, many linguists are, nowadays focusing their studies on the exploration of Hallidayan three metafunctions of language in non-fictional and/or fictional discourses/texts (oral or written). Hopefully through accuracy and conciseness, Kaine Agary, in her fiction, has used language as a resource not only for talking about her inner and outer experiences of the world, but also for establishing and managing relationship through some monologic and dialogic patterns. 


\section{Theoretical Background}

\subsection{A Brief Account on Interpersonal Metafunction}

The theoretical backbone adopted in this article draws on the Hallidayan functional linguistics which contends that language has evolved to simultaneously express three different types of meaning: ideational, interpersonal and textual. The main argument in this theory, as observed by Halliday and Matthiessen (2004), is that interpersonal meaning acts as the grammar of language serving as resource not only for talking about our inner and outer experiences of the world but also for communicating our attitudes towards, and expectations of those with whom we interact. As such, Interpersonal metafunction deals with people's use of language to relate to their audience, because when people embark on human interaction, they take on a series of speech roles, the first two of which are identified as 'giving' and 'demanding' which result in the second choice between 'exchanging information' or 'exchanging goods and services'. This includes the various ways the speaker enters a speech situation and performs a speech act. The four basic moves of 'statement', 'question', 'offer' and 'command' are what Halliday refers to as 'speech functions' (Eggins, 2004, pp. 144-145). Interpersonal meaning is analyzed mainly in terms of 'mood' and 'modality'. A mood analysis brings to the fore the grammatical structures that project the various speech functions.

Modality refers to a speaker's/writer's/narrator's attitude towards, and opinions about the events and situations around him/her (Simpson, 1993, p. 47). Fowler (1986) defines modality as "the grammar of explicit comment, the means by which people express their degree of commitment to the truth of the propositions they utter, and their views on the desirability or otherwise of the state of affairs referred to" (p. 131). Moreover, it has to do with the interpersonal 'coloring' of utterances in terms of probability, usuality, obligation and inclination, thus encoding the attitude of either the characters or the narrator. SFL scholars generally contend that modality can be expressed in two main axes: Epistemic and Deontic Modality.

Epistemic Modality, also referred to as Modalization in SFL terms, is a kind of connotative meaning relating to the degree of certainty the speaker/writer wants to express about what he or she is saying or the estimation of probability associated to the message that is being conveyed through the discourse, (Fontaine, 2013, p. 121). In philosophical semantics, probability is referred to as 'epistemic modality'.

Deontic Modality, also called Modulation in SFL terms, is also a connotative meaning, but contrary to the epistemic modality, it relates to obligation or permission, including willingness or ability. In other words, Modulation is a complex area of English grammar which has to do with the different ways in which a language user can intrude on his/her message, expressing attitudes and judgments of various kinds (Eggins, 2004, p. 172). In other words, philosophical semantics regards obligation as deontic.

According to Fontaine (2013), modality is expressed by nine (09) auxiliary verbs (can, could, shall, should, will, would, may, might, must) and various lexical items (usually adverbs such as probably) or groups which function as modal adjuncts. Other linguistic elements such as vocatives and naming are also of relevance to the construction of interpersonal relations. Table 1 below presents the various Mood Types and their correlating speech functions.

Table 1. Mood Types and their speech functions (culled from Eggins, 2004).

\begin{tabular}{lll}
\hline No & Mood types & Speech functions \\
\hline $\mathbf{1}$ & -declarative mood & -giving information by stating what is or happens \\
$\mathbf{2}$ & -interrogative mood & -request of information \\
$\mathbf{3}$ & -modulated interrogative mood & -indirect/tempered request of information \\
$\mathbf{4}$ & -imperative mood & -getting someone to do something \\
$\mathbf{5}$ & -modulated imperative mood & -getting indirectly/in a tempered way somebody to do something \\
& & by using, say polite modals \\
$\mathbf{6}$ & -exclamative mood & -expressing wonder, surprise, bewilderment \\
\hline
\end{tabular}

\subsection{Defining Critical Discourse Analysis}

Critical Discourse Analysis (CDA) is a form of discourse that takes critical stance towards how language is used. It analyzes other discourse types with a view to identifying the ideology and values underlying them. In this regard, CDA investigates the relations between language and society. It assumes that language plays a crucial role in creating, maintaining and legitimating inequality, injustice and oppression in society. The most important 
aims of CDA are to raise awareness of the power of linguistic constructivism (language construing reality) and its impact and, to trigger change (Nørgaard, et al., 2010, p. 69).

The Hallidayan Systemic Functional Grammar particularly suits CDA because of its orientation towards context, that is, situational, generic, cultural and ideological. Furthermore, its three-dimension approach to language - the textual, interpersonal and ideational — provides CDA with a broad range of grammatical tools for analysis as well as a theoretical framework. These allow the analyst to disclose the ideologically loaded as well as constructed nature of discourses and 'enacted hegemonic genres - specific ways of using language to achieve purposes of social domination' (Van Leeuwen, 2006a, p. 290).

\subsection{A Brief Account of Womanist Theory}

Womanism is a woman-centered ideology derived from Feminism, which is a social movement viewing the male counterpart as primary enemy. Therefore, contrary to Feminism, the womanist theory views male and female as social partners and, is committed to the survival of the wholeness of the entire people. Womanism is, of course, an inclusive theory centered on the natural order of things in the nature, society, and family. According to Layli Phillips (2006), Womanism is a social change perspective rooted in Black women's and other women of colour's everyday experiences and everyday methods of problem solving in every spaces, extended to the problem of ending all forms of oppression, restoring the balance between people and environment/nature, and reconciling human life with the spiritual dimension. Emanating from the critical thinking ventured by Walker Alice in her Womanism, and two other authors, namely, Okonjo Ogunyemi with her perspective on African Womanism, and Hudson-Weems' Africana Womanism, this theory has come up with forming the collective basis for an interpolated field of theory and praxis used by a host of people to follow. Considering that Black women experience sexism, and Womanism being concerned with sexism, Feminism is confluent with the expression of Womanism, but Feminism and Womanism cannot be conflated, nor can it be said that Womanism is a "version" of Feminism. In spite of the speculations sprouting around womanist theory, its scholars and proponents contend that Womanism manifests five overarching characteristics: $1^{\circ}$ ) it is anti-oppressionist; $2^{\circ}$ ) it is vernacular; $3^{\circ}$ ) it is non-ideological; $4^{\circ}$ ) it is communitarian; and $5^{\circ}$ ) it is spiritualized. The non-ideological characteristic makes this theory be confluent with, and inclusively pliable to any theories, one of which is the Hallidayan theory.

\section{Practical Interpersonal Metafunction Analysis in the Extract}

The keys adopted for the Mood analysis of the extracts are as follows:

$[\mathrm{S}]=$ Subject $[\mathrm{F}]=$ Finite $[\mathrm{Fn}]=$ Finite negative; $[\mathrm{Fms}]=$ Finite modalised; $[\mathrm{Fml}]=$ Finite modulated; $[\mathrm{P}]=$ Predicator; $[\mathrm{Pml}]=$ Modulated Predicator; $[\mathrm{Pms}]=$ modalised Predicator; $[\mathrm{F} / \mathrm{P}]=$ fused Finite and Predicator; $[\mathrm{C}]$ = Complement; $[\mathrm{Ca}]=$ attributive Complement; $[\mathrm{A}]=$ Adjunct; $[\mathrm{Ac}]=$ Adjunct Circumstantial; $[\mathrm{Am}]=$ Adjunct mood; $[\mathrm{Ao}]=$ Adjunct comment; $[\mathrm{Ap}]=$ Adjunct polarity; $[\mathrm{Av}]=$ Adjunct vocative; $[\mathrm{Aj}]=$ Adjunct conjunctive; $[\mathrm{At}]=$ Adjunct continuity; $[\mathrm{WH}]=\mathrm{WH}$-element; $[\mathrm{WH} / \mathrm{S}],[\mathrm{WH} / \mathrm{C}],[\mathrm{WH} / \mathrm{Ac}]=$ fused $\mathrm{WH}$ element.

\subsection{Analysis Identifying Deontic, Epistemic Modality and Mood Patterns in the Extract}

The day after my eighteenth birthday [Ac], Admiral $[\mathrm{S}]$ handed $[\mathrm{F} / \mathrm{P}]$ me $[\mathrm{C}]$ a check for seventy-five thousand naira $[\mathrm{C}]$. It $[\mathrm{S}]$ was $[\mathrm{F}]$ [the largest amount of money anyone $[\mathrm{S}]$ had given $[\mathrm{P}]$ to me $[\mathrm{C}]$ at once $[\mathrm{Ac}]$. It $[\mathrm{S}]$ was $[\mathrm{F}]$ my birthday gift $[\mathrm{C}]$, money $\mathrm{I}[\mathrm{S}]$ was $[\mathrm{F}]$ to spend $[\mathrm{P}]$ wisely $[\mathrm{Ac}]$, to keep $[\mathrm{P}]$ me $[\mathrm{C}]$ comfortable $[\mathrm{Ca}]$ so $[\mathrm{Aj}]$ that I $[\mathrm{S}]$ could $[\mathrm{Fml}]$ focus on $[\mathrm{Pml}]$ my studies $[\mathrm{C}]$. I $[\mathrm{S}]$ did not $[\mathrm{Fml} / \mathrm{n}]$ know $[\mathrm{Pml}][$ how to thank $[\mathrm{P}]$ him [C] for the money, for the gesture [Ac]]] [C]. I [S] could not $[\mathrm{Fml} / \mathrm{n}]$ even begin $[\mathrm{Pml}]$ to imagine what $[\mathrm{WH} / \mathrm{C}] \mathrm{I}[\mathrm{S}]$ would $[\mathrm{Fml}]$ spend $[\mathrm{Pml}]$ the money $[\mathrm{C}]$ on $[\mathrm{Ac}]$, as $[\mathrm{Aj}] \mathrm{I}[\mathrm{S}]$ have $[\mathrm{F}]$ saved up $[\mathrm{P}]$ a reasonable amount $[\mathrm{C}]$ in my bank account $[\mathrm{Ac}]$.

I $[\mathrm{S}]$ was $[\mathrm{F}]$ sending $[\mathrm{P}]$ money $[\mathrm{C}]$ to my mother $[\mathrm{C}]$, but $[\mathrm{Aj}] \mathrm{I}[\mathrm{S}]$ could not $[\mathrm{Fml} / \mathrm{n}]$ send $[\mathrm{Pml}]$ her $[\mathrm{C}]$ too much $[\mathrm{C}]$ at once $[\mathrm{Ac}]$ so $[\mathrm{Aj}]$ that she $[\mathrm{S}]$ believed $[\mathrm{F} / \mathrm{P}]$ it $[\mathrm{S}]$ was $[\mathrm{F}]$ all coming $[\mathrm{P}]$ from my salary or respectable $[\mathrm{Ca}]$ work-related dealings $[\mathrm{Ac}]$. Though $[\mathrm{Aj}] \mathrm{I}[\mathrm{S}]$ was not $[\mathrm{Fn}]$ with her $[\mathrm{Ca}], \mathrm{I}[\mathrm{S}]$ was $[\mathrm{F}]$ still $[\mathrm{Am}]$ very concerned $[\mathrm{Ca}]$ about what $[\mathrm{WHC}]$ she $[\mathrm{S}]$ thought $[\mathrm{F} / \mathrm{P}]$ and continuously $[\mathrm{Am}]$ heard $[\mathrm{P}]$ her voice $[\mathrm{C}]$ in my head $[\mathrm{Ac}]$, especially $[\mathrm{Ao}]$ when $[\mathrm{WH} / \mathrm{Ac}] \mathrm{I}[\mathrm{S}]$ felt $[\mathrm{F} / \mathrm{P}]$ guilty about something $[\mathrm{Ca}]$.

"Admiral, this $[\mathrm{S}]$ is $[\mathrm{F}]$ too much money $[\mathrm{Ca}]$, , I $[\mathrm{S}]$ protested $[\mathrm{F} / \mathrm{P}]$.

"I [S] don't [Fml/n] want [Pml] you [C] [[to have [P] any excuses [C] for not passing your exams [Ac]]]. I [S] want $[\mathrm{F} / \mathrm{P}]$ you $[\mathrm{C}]$ to focus on your studies $[\mathrm{Ac}]$ and on passing your exams $[\mathrm{Ac}]$, then $[\mathrm{Aj}]$ we' $[\mathrm{S}] \mathrm{ll}[\mathrm{Fml}]$ worry $[\mathrm{Pml}]$ about the rest $[\mathrm{Ac}]$, , he $[\mathrm{S}]$ insisted $[\mathrm{F} / \mathrm{P}]$.

I [S] owed [F/P] it [C] to myself [C] [[to succeed in my exams [C]]], but [Aj] now [Aj] I [S] also owed [F/P] it $[\mathrm{C}]$ to so many other people- my mother, Sisi, Lolo, and $[\mathrm{Aj}]$ now $[\mathrm{Ac}]$ Admiral $[\mathrm{C}]$. I [S] felt like $[\mathrm{F} / \mathrm{P}]$ it $[\mathrm{S}]$ 
was $[\mathrm{F}]$ only $[\mathrm{Am}]$ a matter of time before $\mathrm{I}[\mathrm{S}]$ crashed $[\mathrm{F} / \mathrm{P}]$. The streets from my village to where $[\mathrm{WH} / \mathrm{C}] \mathrm{I}[\mathrm{S}]$ was $[\mathrm{F}]$ now $[\mathrm{Ac}]$ had $[\mathrm{F}]$ been paved $[\mathrm{P}]$ with gold $[\mathrm{C}]$. No one $[\mathrm{S}]$ was $[\mathrm{F}]$ blessed $[\mathrm{P}]$ with so much luck $[\mathrm{C}]$. Even [I, who [WH/S] had [F] been blessed [P] with so much in less than a year in Port Harcourt $[\mathrm{C}]]$,$] [S] could$ not $[\mathrm{Fms} / \mathrm{n}]$ be $[\mathrm{Pms}]$ foolish $[\mathrm{Ca}]$ enough $[\mathrm{Ao}]$ to believe $[\mathrm{P}]$ that life $[\mathrm{S}]$ was $[\mathrm{F}]$ really $[\mathrm{Ao}]$ like this $[\mathrm{Ca}]$. Whatever [WH/C] spirit I [S] had to [Fml] thank [Pml] for all my luck[Ac], I [S] thanked [F/P] her [C] and [Aj] prayed $[\mathrm{F} / \mathrm{P}]$ that she $[\mathrm{S}]$ would not $[\mathrm{Fml} / \mathrm{n}]$ turn $[\mathrm{Pml}]$ her back $[\mathrm{C}]$ on me $[\mathrm{Ac}]$. I $[\mathrm{S}]$ believe $[\mathrm{F} / \mathrm{P}]$ it $[\mathrm{S}]$ had to [Fms] be [Pms] a female spirit with a mother's compassion [Ca]. And [Aj] for that I [S] had to [Fms] be [Pms] very careful not to offend her $[\mathrm{Ca}]$, because $[\mathrm{Aj}]$ female spirits $[\mathrm{S}]$ unleashed $[\mathrm{F} / \mathrm{P}]$ the worst punishments $[\mathrm{C}]$ when $[\mathrm{WH} / \mathrm{A}]$ they $[\mathrm{S}]$ were $[\mathrm{F}]$ offended $[\mathrm{P}]$.

I $[\mathrm{S}]$ was $[\mathrm{F}]$ spending $[\mathrm{P}]$ less time with Lolo $[\mathrm{C}]$ because $[\mathrm{Aj}]$ every spare moment $[\mathrm{C}] \mathrm{I}[\mathrm{S}]$ had $[\mathrm{F}] \mathrm{I}[\mathrm{S}]$ wanted to spend $[\mathrm{P}]$ with Admiral[C]. My days $[\mathrm{S}]$ were $[\mathrm{F}]$ full $[\mathrm{Ca}]$ before I $[\mathrm{S}]$ started $[\mathrm{P}]$ my relationships $[\mathrm{C}]$ with Admiral [C], $[\mathrm{C}]$ but $[\mathrm{Aj}]$ then $[\mathrm{Aj}]$ most of my time $[\mathrm{S}]$ was $[\mathrm{F}]$ spent $[\mathrm{P}]$ with Lolo $[\mathrm{C}]$, or at least she $[\mathrm{S}]$ knew $[\mathrm{F} / \mathrm{P}]$ where $[\mathrm{WH} / \mathrm{Ac}] \mathrm{I}[\mathrm{S}]$ was $[\mathrm{F}]$. I $[\mathrm{S}]$ started lying $[\mathrm{P}]$ to her and $[\mathrm{Aj}]$ avoiding $[\mathrm{P}]$ her $[\mathrm{C}]$. She $[\mathrm{S}]$ suspected $[\mathrm{F} / \mathrm{P}] \mathrm{I}[\mathrm{S}]$ had $[\mathrm{F}]$ a boyfriend $[\mathrm{C}]$, and $[\mathrm{Aj}]$ one day $[\mathrm{Ac}]$ when $[\mathrm{WH} / \mathrm{Ac}] \mathrm{I}[\mathrm{S}]$ was $[\mathrm{F}]$ with her $[\mathrm{C}]$ in her bedroom $[\mathrm{Ac}]$, she $[\mathrm{S}]$ asked $[\mathrm{F} / \mathrm{P}]$ when $[\mathrm{WH} / \mathrm{Ac}]$ she $[\mathrm{S}]$ was $[\mathrm{F}]$ going to meet $[\mathrm{P}]$ the boy $[\mathrm{C}]$ who $[\mathrm{WH} / \mathrm{S}]$ was $[\mathrm{F}]$ keeping $[\mathrm{P}]$ me $[\mathrm{C}]$ occupied. I $[\mathrm{S}]$ opened $[\mathrm{F} / \mathrm{P}]$ my mouth $[\mathrm{C}]$ in shock $[\mathrm{Ac}]$; she $[\mathrm{S}]$ had $[\mathrm{F}]$ caught $[\mathrm{P}]$ me $[\mathrm{C}]$ off guard $[\mathrm{Ac}]$, not just $[\mathrm{Aj}]$ by her question $[\mathrm{C}]$ but $[\mathrm{Aj}]$ also by the seriousness of her tone $[\mathrm{Ac}]$.

"I [S] don’t $[\mathrm{Fml} / \mathrm{n}]$ have $[\mathrm{Pml}]$ a boyfriend," [C] I [S] managed $[\mathrm{F} / \mathrm{P}]$ to say after I $[\mathrm{S}]$ had $[\mathrm{F}]$ recovered $[\mathrm{P}]$ from my shock $[\mathrm{Ac}]$. "What $[\mathrm{WH} / \mathrm{C}]$ is $[\mathrm{F}]$ your boyfriend's name $[\mathrm{S}]$ ?" $[\mathrm{S}]$ Lolo $[\mathrm{S}]$ was $[\mathrm{F}]$ very serious $[\mathrm{Ca}]$. "I $[\mathrm{S}]$ don't $[\mathrm{Fml} / \mathrm{n}]$ have $[\mathrm{Pml}]$ a boyfriend $[\mathrm{C}]$," I $[\mathrm{S}]$ blurred $[\mathrm{F} / \mathrm{P}]$ out $[\mathrm{Ac}]$, very embarrassed $[\mathrm{F} / \mathrm{P}]$ by the question $[\mathrm{Ac}]$.

"Don't $[\mathrm{Fml} / \mathrm{n}]$ lie $[\mathrm{Pml}]$ to me $[\mathrm{C}]$. I [S] know [F/P] you [S] have [F] a boyfriend [C]. I [S] can [Fml] tell [Pml]. Besides $[\mathrm{Aj}]$, Sisi $[\mathrm{S}]$ says $[\mathrm{F} / \mathrm{P}]$ she $[\mathrm{S}]$ hardly $[\mathrm{Am}]$ sees $[\mathrm{F} / \mathrm{P}]$ you $[\mathrm{C}]$ at home these days $[\mathrm{Ac}]$, and $[\mathrm{Aj}] \mathrm{I}[\mathrm{S}]$ have not $[\mathrm{Fn}]$ been seeing $[\mathrm{P}]$ you $[\mathrm{C}]$ as frequently as before $[\mathrm{Ac}]$. If you $[\mathrm{S}]$ don't $[\mathrm{Fml} / \mathrm{n}]$ want $[\mathrm{Pml}]$ to tell me $[\mathrm{C}]$, that $[\mathrm{S}]$ 's $[\mathrm{F}]$ fine $[\mathrm{Ca}]$, but $[\mathrm{Aj}] \mathrm{I}[\mathrm{S}]$ will $[\mathrm{Fml}]$ find out[Pml], and $[\mathrm{Aj}]$ he $[\mathrm{S}]$ better not be $[\mathrm{F}]$ some riffraff [Ca]."

"I [S] don't [Fml/n] have [Pml] a boyfriend" [C], [C] I [S] insisted. [F/P]

"Well, $[\mathrm{Aj}]$ just $[\mathrm{Aj}]$ don't $[\mathrm{Fml} / \mathrm{n}]$ let $[\mathrm{Pml}]$ any boy distract $[\mathrm{P}]$ you $[\mathrm{C}]$ o! I $[\mathrm{S}]$ hope $[\mathrm{F} / \mathrm{P}]$ all these times I $[\mathrm{S}]$ don't $[\mathrm{Fml} / \mathrm{n}]$ see $[\mathrm{Pml}]$ you, $[\mathrm{C}]$ you $[\mathrm{S}]$ are $[\mathrm{F}]$ somewhere studying for your exams." She $[\mathrm{S}]$ was not $[\mathrm{Fn}]$ pushing $[\mathrm{P}]$ the subject $[\mathrm{C}]$ any further.

"Yes, [Ap] ma," I [S] responded [F/P] cheekily [Ao]

"Don't $[\mathrm{Fml} / \mathrm{n}]$ pass $[\mathrm{Pml}]$ and $[\mathrm{Aj}]$ you $[\mathrm{S}]$ will $[\mathrm{Fml}]$ see $[\mathrm{Pml}]$ what $[\mathrm{WH} / \mathrm{C}] \mathrm{I}[\mathrm{S}]$ will $[\mathrm{Fml}]$ do $[\mathrm{Pml}]$ to you," she $[\mathrm{S}]$ threatened $[\mathrm{F} / \mathrm{P}]$ as $[\mathrm{Aj}]$ she $[\mathrm{S}]$ tapped $[\mathrm{F} / \mathrm{P}]$ the back of my head $[\mathrm{C}]$. She $[\mathrm{S}]$ said $[\mathrm{F} / \mathrm{P}]$ it $[\mathrm{C}]$ with a smile $[\mathrm{Ac}]$, but $[\mathrm{Aj}] \mathrm{I}[\mathrm{S}]$ knew $[\mathrm{F} / \mathrm{P}]$ that she $[\mathrm{S}]$ would $[\mathrm{Fml}]$ give $[\mathrm{Pml}]$ me hell $[\mathrm{C}]$ if I $[\mathrm{S}]$ did not $[\mathrm{Fml} / \mathrm{n}]$ do $[\mathrm{Pml}]$ well $[\mathrm{Aj}]$ in the exams. I $[\mathrm{S}]$ also knew $[\mathrm{F} / \mathrm{P}]$ that if she $[\mathrm{S}]$ wanted $[\mathrm{F} / \mathrm{P}]$ to, she $[\mathrm{S}]$ could $[\mathrm{Fml}]$ easily $[\mathrm{Ao}]$ find out $[\mathrm{Pml}]$ who $[\mathrm{WH} / \mathrm{C}] \mathrm{I}[\mathrm{S}]$ was $[\mathrm{F}]$ having $[\mathrm{P}]$ a relationship $[\mathrm{C}]$ with, and $[\mathrm{Aj}]$ that unsettled $[\mathrm{F} / \mathrm{P}]$ me. $[\mathrm{C}]$

Sisi $[\mathrm{S}]$ was $[\mathrm{F}]$ old $[\mathrm{Ca}]$ and $[\mathrm{Aj}]$ had $[\mathrm{F}]$ made $[\mathrm{P}]$ it $[\mathrm{C}]$ clear $[\mathrm{Ca}]$ from the beginning that she $[\mathrm{S}]$ had $[\mathrm{F}]$ no energy $[\mathrm{C}]$ to chase me $[\mathrm{C}]$ around $[\mathrm{Ac}]$, so $[\mathrm{Aj}]$ Lolo $[\mathrm{S}]$ took $[\mathrm{F} / \mathrm{P}]$ very seriously $[\mathrm{Ac}]$ her duty $[\mathrm{C}]$ to take care $[\mathrm{P}]$ of $\mathrm{me}[\mathrm{C}]$ and $[\mathrm{Aj}]$ what $[\mathrm{WH} / \mathrm{S}]$ was $[\mathrm{F}]$ best for my future $[\mathrm{Ca}]$. In fact $[\mathrm{Aj}]$, Sisi $[\mathrm{S}]$ usually $[\mathrm{Am}]$ talked $[\mathrm{F} / \mathrm{P}]$ to Lolo $[\mathrm{C}]$ to find out what $[\mathrm{WH} / \mathrm{C}] \mathrm{I}[\mathrm{S}]$ was $[\mathrm{F}]$ up to $[\mathrm{Ca}]$, and $[\mathrm{Aj}]$ as long as $[\mathrm{Aj}] \mathrm{I}[\mathrm{S}]$ was $[\mathrm{F}]$ with Lolo $[\mathrm{C}]$, or Lolo $[\mathrm{S}]$ approved $[\mathrm{F} / \mathrm{P}]$ of what $[\mathrm{WH} / \mathrm{C}] \mathrm{I}[\mathrm{S}]$ was $[\mathrm{F}]$ doing $[\mathrm{P}]$, it $[\mathrm{S}]$ was $[\mathrm{F}]$ okay $[\mathrm{Ca}]$ with her [Ac].

As long as $[\mathrm{Aj}] \mathrm{I}[\mathrm{S}]$ was $[\mathrm{F}]$ able $[\mathrm{Ca}]$ to dribble everyone $[\mathrm{C}]$ to carry on my affair [C] with Admiral [Ac], I [S] did $[\mathrm{F}]$. For a while $[\mathrm{Ac}], \mathrm{I}[\mathrm{S}]$ did not $[\mathrm{Fml} / \mathrm{n}]$ have $[\mathrm{Pml}]$ the watchful eyes $[\mathrm{C}]$ of Lolo on me $[\mathrm{Ac}]$. She $[\mathrm{S}]$ had $[\mathrm{F}]$ wanted $[\mathrm{P}]$ to spend Valentine's Day $[\mathrm{C}]$ with Kamal $[\mathrm{Ac}]$, and $[\mathrm{Aj}]$ he $[\mathrm{S}]$ had $[\mathrm{F}]$ come up $[\mathrm{P}]$ with an excuse $[\mathrm{C}]$ why $[\mathrm{WH} / \mathrm{A}]$ he $[\mathrm{S}]$ could not $[\mathrm{Fms} / \mathrm{n}]$ be $[\mathrm{Pms}]$ in Port Harcourt and $[\mathrm{Aj}]$ why $[\mathrm{WH} / \mathrm{A}]$ Lolo $[\mathrm{S}]$ could not $[\mathrm{Fms} / \mathrm{n}]$ visit $[\mathrm{Pms}]$ him $[\mathrm{C}]$ in Lagos $[\mathrm{Ac}]$. She $[\mathrm{S}]$ ignored $[\mathrm{F} / \mathrm{P}]$ him $[\mathrm{C}]$ and $[\mathrm{Aj}]$ went $[\mathrm{F} / \mathrm{P}]$ away $[\mathrm{Ac}]$; though $[\mathrm{Aj}] \mathrm{I}[\mathrm{S}]$ was $[\mathrm{F}]$ privy $[\mathrm{Ca}]$ to the details $[\mathrm{C}], \mathrm{I}[\mathrm{S}]$ knew $[\mathrm{F} / \mathrm{P}]$ things had not $[\mathrm{Fn}]$ gone $[\mathrm{P}]$ well $[\mathrm{Aj}]$ during that visit $[\mathrm{Ac}]$. Shortly after that $[\mathrm{Ac}]$, Lolo $[\mathrm{S}]$ took off $[\mathrm{F} / \mathrm{P}]$ to London $[\mathrm{Ac}]$ for almost two weeks $[\mathrm{Ac}]$, and $[\mathrm{Aj}]$ when $[\mathrm{WH} / \mathrm{A}]$ she $[\mathrm{S}]$ got $[\mathrm{P}]$ back $[\mathrm{Ac}]$, it $[\mathrm{S}]$ was $[\mathrm{F}]$ even $[\mathrm{Aj}]$ more apparent that things $[\mathrm{S}]$ were not $[\mathrm{Fn}]$ well $[\mathrm{Ca}]$ between them $[\mathrm{Ac}]$. Lolo's hours $[\mathrm{S}]$ had never $[\mathrm{Fn}]$ been $[\mathrm{P}]$ complete $[\mathrm{Ca}]$ without at least three references to Kamal [Ac]; then [Aj], suddenly [Am], there [S] was no [Fn] talk of Kamal [Ca]. It [S] seemed $[\mathrm{F} / \mathrm{P}]$ everyone else $[\mathrm{S}]$ was $[\mathrm{F}]$ in on the secret $[\mathrm{Ac}]$ because $[\mathrm{Aj}]$ they $[\mathrm{S}]$ didn't $[\mathrm{Fml} / \mathrm{n}]$ bring up [Pml] 
his name $[\mathrm{C}]$ either. I $[\mathrm{S}]$ asked $[\mathrm{F} / \mathrm{P}]$ her $[\mathrm{C}]$ one day $[\mathrm{Ac}]$ about my brother-in-law $[\mathrm{Ac}]$, and $[\mathrm{Aj}]$ she $[\mathrm{S}]$ gruffly $[$ Ao] asked $[\mathrm{F} / \mathrm{P}]$ me $[\mathrm{C}]$ not to spoil $[\mathrm{P}]$ her day $[\mathrm{C}]$. She $[\mathrm{S}]$ had $[\mathrm{F}]$ become $[\mathrm{P}]$ grumpy and withdrawn $[\mathrm{Ca}]$, spending $[\mathrm{P}]$ more time at home than with Sisi or me $[\mathrm{C}] .(\ldots)$

There [S] would [Fms] be [Pms] more days like that [Ca]. Days when [WH/Ac] I [S] would [Fms] be [Pms] so [Aj] close [Ca] to Admiral [Ca], in his house [Ac], but [Aj] unable [Ca] to see him [C], or if [Aj] I [S] did [Fml] see $[\mathrm{Pml}]$ him $[\mathrm{C}]$, it $[\mathrm{S}]$ was $[\mathrm{F}]$ for five to ten minutes $[\mathrm{Ac}]$ because $[\mathrm{Aj}]$ he $[\mathrm{S}]$ was $[\mathrm{F}]$ discussing $[\mathrm{P}]$ politics $[\mathrm{C}]$ in his living room [Ac]. Days when [WH/A] he [S] would [Fml] meet $[\mathrm{Pml}] \mathrm{me}[\mathrm{C}]$ in his bedroom $[\mathrm{Ac}]$, hastly $[\mathrm{Ao}]$ ask $[\mathrm{P}]$ how $\mathrm{I}[\mathrm{S}]$ was $[\mathrm{F}]$ doing $[\mathrm{P}]$, and $[\mathrm{Aj}]$ put $[\mathrm{P}]$ a wad of money $[\mathrm{C}]$ in my handbag so $[\mathrm{Aj}]$ that he $[\mathrm{S}]$ could $[\mathrm{Fml}]$ return $[\mathrm{Pml}]$ to the discussions $[\mathrm{C}]$ in his living room $[\mathrm{Ac}]$. They $[\mathrm{S}]$ talked $[\mathrm{F} / \mathrm{P}]$ about how the oil companies $[\mathrm{S}]$ were $[\mathrm{Fn}]$ using $[\mathrm{P}]$ the Nigerian Armed forces $[\mathrm{C}]$ as their private security details to terrorise $[\mathrm{P}]$ and $[\mathrm{Aj}]$ sometimes $[\mathrm{Am}]$ kill $[\mathrm{P}]$ innocent villagers $[\mathrm{C}]$ who $[\mathrm{WH} / \mathrm{S}]$ questioned $[\mathrm{F} / \mathrm{P}]$ the inequity of their situation $[\mathrm{C}]$ - living $[\mathrm{P}]$ in squalor while $[\mathrm{Aj}]$ barrels of oil pumped out of their land $[\mathrm{S}]$ provided $[\mathrm{F} / \mathrm{P}]$ the luxury $[\mathrm{C}]$ that $[\mathrm{WH} / \mathrm{S}]$ surrounded $[\mathrm{F} / \mathrm{P}]$ the oil workers and the elite of Nigeria $[\mathrm{C}]$. They $[\mathrm{S}]$ held $[\mathrm{F} / \mathrm{P}]$ heated debates $[\mathrm{C}]$ about which $[\mathrm{WH} / \mathrm{C}]$ Ijaw man $[\mathrm{S}]$ had $[\mathrm{F}]$ disappointed $[\mathrm{P}]$ the entire group $[\mathrm{C}]$ as a people by his nonperformance in a position of political or economic power $[\mathrm{Ac}]$. There $[\mathrm{S}]$ were $[\mathrm{F}]$ discussions $[\mathrm{C}]$ about who $[\mathrm{WH} / \mathrm{S}]$ would $[\mathrm{Fms}]$ be $[\mathrm{Pms}]$ suitable $[\mathrm{Ca}]$ candidates $[\mathrm{Ca}]$ for political power if and $[\mathrm{Aj}]$ when $[\mathrm{WH} / \mathrm{A}]$ the opportunity $[\mathrm{S}]$ came, $[\mathrm{F} / \mathrm{P}]$ and $[\mathrm{Aj}]$ more talk about how to move $[\mathrm{P}]$ the Ijaw Nation $[\mathrm{C}]$ forward $[\mathrm{Ac}]$, economically and socially $[\mathrm{Ac}]$. Yes, $[\mathrm{Ap}]$ these discussions $[\mathrm{S}]$ were $[\mathrm{F}]$ important $[\mathrm{Ca}]$, but $[\mathrm{Aj}]$ what $[\mathrm{WH} / \mathrm{S}]$ was $[\mathrm{F}]$ more important to me $[\mathrm{S}]$ was $[\mathrm{F}]$ to have $[\mathrm{P}]$ Admiral's undivided $[\mathrm{Ca}]$ attention $[\mathrm{C}]$.

As $[\mathrm{Aj}]$ my exam date $[\mathrm{S}]$ got $[\mathrm{P}]$ closer $[\mathrm{Ca}], \mathrm{I}[\mathrm{S}]$ put $[\mathrm{F} / \mathrm{P}]$ all my energy and the pieces of my heart $[\mathrm{C}]$ into my studies $[\mathrm{Ac}]$. I $[\mathrm{S}]$ had not $[\mathrm{Fn}]$ given $[\mathrm{P}]$ myself $[\mathrm{C}]$ much time to study for the exams, so [Aj] I [S] just [Aj] crammed $[\mathrm{F} / \mathrm{P}]$. I $[\mathrm{S}]$ lived $[\mathrm{F} / \mathrm{P}]$ on my books $[\mathrm{C}]$. Sleep and $[\mathrm{Aj}]$ hunger $[\mathrm{S}]$ stayed $[\mathrm{F} / \mathrm{P}]$ away from $\mathrm{me}$ as $[\mathrm{Aj}]$ if conspiring $[\mathrm{P}]$ and $[\mathrm{Aj}]$ then $[\mathrm{Aj}]$ deciding to be part of the emotional torture $\mathrm{I}[\mathrm{S}]$ was $[\mathrm{F}]$ enduring $[\mathrm{P}]$.

By late March, only days away from my exams $[\mathrm{Ac}]$, my body $[\mathrm{S}]$ had $[\mathrm{F}]$ given up $[\mathrm{P}]$. I $[\mathrm{S}]$ was $[\mathrm{F}]$ dragging $[\mathrm{P}]$ myself $[\mathrm{C}]$ around $[\mathrm{Ac}]$. My eyes $[\mathrm{S}]$ were $[\mathrm{F}]$ swollen $[\mathrm{P}]$ and red $[\mathrm{Ca}]$, my skin $[\mathrm{S}]$ was $[\mathrm{F}]$ pale, and $[\mathrm{Aj}]$ my lips $[\mathrm{S}]$ were $[\mathrm{F}]$ red $[\mathrm{Ca}]$ from my nervous biting $[\mathrm{C}]$. Mr. Moses $[\mathrm{S}]$ kindly $[\mathrm{Ao}]$ gave $[\mathrm{F} / \mathrm{P}]$ me $[\mathrm{C}]$ time off work $[\mathrm{C}]$ until $[\mathrm{Aj}] \mathrm{I}[\mathrm{S}]$ finished $[\mathrm{F} / \mathrm{P}]$ my exams $[\mathrm{C}]$. Sisi and $[\mathrm{Aj}]$ Lolo $[\mathrm{S}]$ were $[\mathrm{F}]$ worried $[\mathrm{P}]$ and $[\mathrm{Aj}]$ ordered $[\mathrm{F} / \mathrm{P}]$ me $[\mathrm{C}]$ to rest. They $[\mathrm{S}]$ took $[\mathrm{F} / \mathrm{P}]$ away my books $[\mathrm{C}]$ one weekend $[\mathrm{Ac}]$, forced $[\mathrm{F} / \mathrm{P}]$ me $[\mathrm{C}]$ to eat, and $[\mathrm{Aj}]$ gave $[\mathrm{F} / \mathrm{P}]$ me $[\mathrm{C}]$ Valium $[\mathrm{C}]$ to help me $[\mathrm{C}]$ sleep $[\mathrm{P}]$.

I $[\mathrm{S}]$ was $[\mathrm{F}]$ so lost $[\mathrm{Ca}]$ in my own world $[\mathrm{Ac}]$ that I $[\mathrm{S}] \operatorname{did}$ not $[\mathrm{Fml} / \mathrm{n}]$ notice $[\mathrm{Pml}]$ the fanfare $[\mathrm{C}]$ for the Pope's visit to Nigeria $[\mathrm{C}]$. There $[\mathrm{S}]$ were $[\mathrm{F}]$ special masses, meetings in Abuja, prayers, and so on [C]. Even the head of state, who $[\mathrm{WH} / \mathrm{S}]$ was $[\mathrm{F}]$ making $[\mathrm{P}]$ very limited public appearances $[\mathrm{C}],[\mathrm{S}]$ made $[\mathrm{F} / \mathrm{P}]$ an appearance $[\mathrm{C}]$ for the Pope $[\mathrm{C}]$.

Physically $[\mathrm{Ac}] \mathrm{I}[\mathrm{S}]$ was $[\mathrm{F}]$ in poor shape $[\mathrm{Ca}]$, but $[\mathrm{Aj}] \mathrm{I}[\mathrm{S}]$ managed $[\mathrm{F} / \mathrm{P}]$ to write all my exams $[\mathrm{C}]$. By the time $[\mathrm{Aj}]$ it $[\mathrm{S}]$ was $[\mathrm{F}]$ over $[\mathrm{Ca}], \mathrm{I}[\mathrm{S}]$ was $[\mathrm{F}]$ feeling $[\mathrm{P}]$ more relaxed but $[\mathrm{Aj}]$ still very tired $[\mathrm{Ca}]$. Sisi $[\mathrm{S}]$ took $[\mathrm{F} / \mathrm{P}]$ me $[\mathrm{C}]$ to her doctor $[\mathrm{Ac}]$, and $[\mathrm{Aj}]$ without a physical exam $[\mathrm{Ac}]$, he $[\mathrm{S}]$ stated $[\mathrm{P}]$ that my body $[\mathrm{S}]$ was $[\mathrm{F}]$ just $[\mathrm{Am}]$ reacting $[\mathrm{P}]$ to the stress under which $[\mathrm{WH} / \mathrm{C}] \mathrm{I}[\mathrm{S}]$ had $[\mathrm{F}]$ put $[\mathrm{P}]$ it $[\mathrm{C}]$. He $[\mathrm{S}]$ gave $[\mathrm{F} / \mathrm{P}]$ me some iron tablets $[\mathrm{C}]$ for my anaemia and $[\mathrm{Aj}]$ Vitamin B complex [C] for energy [Ac]. He [S] promised [F/P] that in no time I [S] would [Fms] feel [Pms] better [Ca].

One $[\mathrm{S}]$ can $[\mathrm{Fml}]$ say $[\mathrm{Pml}]$ sickness or wellness $[\mathrm{S}]$ is $[\mathrm{F}]$ in the mind $[\mathrm{Ca}]$, so $[\mathrm{Aj}]$ when $[\mathrm{WH} / \mathrm{A}] \mathrm{I}[\mathrm{S}]$ was $[\mathrm{F}]$ able to see Admiral $[\mathrm{C}], \mathrm{I}[\mathrm{S}]$ felt $[\mathrm{F} / \mathrm{P}]$ very good $[\mathrm{Ca}]$. I $[\mathrm{S}]$ knew $[\mathrm{F} / \mathrm{P}]$ he $[\mathrm{S}]$ was $[\mathrm{F}]$ busy $[\mathrm{Ca}]$, but $[\mathrm{Aj}] \mathrm{I}[\mathrm{S}]$ could not $[\mathrm{Fml} / \mathrm{n}]$ help $[\mathrm{Pml}]$ but $[\mathrm{Aj}]$ wonder $[\mathrm{P}]$ if $[\mathrm{Aj}]$ he $[\mathrm{S}]$ had $[\mathrm{F}]$ moved $[\mathrm{P}]$ on to another young $[\mathrm{Ca}]$ girl $[\mathrm{C}]$. After all $[\mathrm{Ac}]$, he $[\mathrm{S}]$ did $[\mathrm{Fml}]$ have $[\mathrm{Pml}]$ a reputation $[\mathrm{C}]$ for liking very young girls $[\mathrm{Ac}]$. I $[\mathrm{S}]$ had not $[\mathrm{Fn}]$ heard $[\mathrm{P}]$ anything $[\mathrm{C}]$, but $[\mathrm{Aj}]$ since $[\mathrm{Aj}]$ nothing $[\mathrm{S}]$ had $[\mathrm{F}]$ leaked $[\mathrm{P}]$ to the tabloids about his affairs with me [C], I [S] was not [Fn] comforted [P].

Emem $[\mathrm{S}]$ tried $[\mathrm{F} / \mathrm{P}]$ to convince me $[\mathrm{C}]$ that $\mathrm{I}[\mathrm{S}]$ was $[\mathrm{F}]$ being $[\mathrm{P}]$ morose where $[\mathrm{WH} / \mathrm{A}]$ there $[\mathrm{S}]$ was $[\mathrm{F}]$ no need $[\mathrm{Fms}]$ to be $[\mathrm{Pms}]$. I $[\mathrm{S}]$ had to $[\mathrm{F}]$ understand $[\mathrm{P}]$ that Admiral $[\mathrm{S}]$ was $[\mathrm{F}]$ a busy man $[\mathrm{C}]$. He $[\mathrm{S}]$ was $[\mathrm{F}]$ good to me when $[\mathrm{WH} / \mathrm{A}]$ he $[\mathrm{S}]$ saw $[\mathrm{F} / \mathrm{P}]$ me $[\mathrm{C}]$, so $[\mathrm{Aj}] \mathrm{I}[\mathrm{S}]$ should $[\mathrm{Fms}]$ be $[\mathrm{Pms}]$ grateful $[\mathrm{Ca}]$ for that $[\mathrm{Ca}]$. I [S] shared $[\mathrm{F} / \mathrm{P}]$ my concern $[\mathrm{C}]$ that I $[\mathrm{S}]$ might $[\mathrm{Fms}]$ be $[\mathrm{Pms}]$ pregnant $[\mathrm{Ca}]$, because $[\mathrm{Aj}] \mathrm{I}[\mathrm{S}]$ had not $[\mathrm{Fn}]$ been feeling $[\mathrm{P}]$ well $[\mathrm{Ca}]$ and $[\mathrm{Aj}]$ my menstrual period $[\mathrm{S}]$ was $[\mathrm{F}]$ very late. She $[\mathrm{S}]$ chucked $[\mathrm{F} / \mathrm{P}]$ it $[\mathrm{C}]$ up to stress and $[\mathrm{Aj}]$ carelessly $[\mathrm{Ao}]$ said $[\mathrm{F} / \mathrm{P}]$ that if $[\mathrm{Aj}] \mathrm{I}[\mathrm{S}]$ was $[\mathrm{F}]$ pregnant $[\mathrm{Ca}]$, it $[\mathrm{S}]$ was not $[\mathrm{Fn}]$ the end of the world $[\mathrm{C}]$ and $[\mathrm{Aj}]$ she $[\mathrm{S}]$ could $[\mathrm{Fml}]$ help $[\mathrm{Pml}]$ me deal with it if necessary. I $[\mathrm{S}]$ was $[\mathrm{F}]$ inclined $[\mathrm{P}]$ to accept stress $[\mathrm{C}]$ as the cause of my delayed period. Apart from the fact that I $[\mathrm{S}]$ occasionally [oj] felt $[\mathrm{F} / \mathrm{P}]$ 
lethargic, I $[\mathrm{S}]$ did not $[\mathrm{Fml} / \mathrm{n}]$ have $[\mathrm{Pml}]$ the morning sickness or dizziness $[\mathrm{C}]$ that $\mathrm{I}[\mathrm{S}]$ had $[\mathrm{F}]$ heard $[\mathrm{P}]$ so much about.

I $[\mathrm{S}]$ wish $[\mathrm{F} / \mathrm{P}] \mathrm{I}[\mathrm{S}]$ could $[\mathrm{Fml}]$ talk $[\mathrm{Pml}]$ to Lolo $[\mathrm{C}]$, but $[\mathrm{Aj}]$ she $[\mathrm{S}]$ was $[\mathrm{F}]$ going $[\mathrm{P}]$ through her own issues with Kamal. Whatever [WH/C] it $[\mathrm{S}]$ was, $[\mathrm{F}]$ no one $[\mathrm{S}]$ talked $[\mathrm{P}]$ about it $[\mathrm{C}]$, but $[\mathrm{Aj}]$ everyone $[\mathrm{S}]$ knew $[\mathrm{F} / \mathrm{P}]$ that Lolo and $[\mathrm{Aj}]$ Kamal $[\mathrm{S}]$ were $[\mathrm{F}]$ on the outs $[\mathrm{Ac}]$. In my eyes $[\mathrm{Ac}]$, they $[\mathrm{S}]$ had $[\mathrm{F}]$ the perfect relationship, $[\mathrm{C}]$ so $[\mathrm{Aj}] \mathrm{I}[\mathrm{S}]$ could not $[\mathrm{Fml} / \mathrm{n}]$ even $[\mathrm{Am}]$ venture $[\mathrm{Pml}]$ a guess $[\mathrm{C}]$ as to what $[\mathrm{WH} / \mathrm{C}]$ their problems $[\mathrm{S}]$ were $[\mathrm{F}]$. Moreover $[\mathrm{Aj}]$, Lolo $[\mathrm{S}]$ left $[\mathrm{F} / \mathrm{P}]$ very little room for intrusion $[\mathrm{C}]$ because $[\mathrm{Aj}]$ she $[\mathrm{S}]$ was $[\mathrm{F}]$ rarely $[\mathrm{Am}]$ in town $[\mathrm{Ac}]$. She $[\mathrm{S}]$ shuttled $[\mathrm{F} / \mathrm{P}]$ between London and Port Harcourt $[\mathrm{Ac}]$ as if she $[\mathrm{S}]$ were $[\mathrm{F}]$ going $[\mathrm{P}]$ from Port Harcourt to Buguma $[\mathrm{Ac}]$. The only person who $[\mathrm{WH} / \mathrm{S}]$ seemed $[\mathrm{F} / \mathrm{P}]$ happy $[\mathrm{Ca}]$ about the situation $[\mathrm{S}]$ was $[\mathrm{F}] \mathrm{Pa}$, Lolo's father $[\mathrm{C}]$, who $[\mathrm{WH} / \mathrm{S}]$ was $[\mathrm{F}]$ just $[\mathrm{Am}]$ happy $[\mathrm{Ca}]$ because $[\mathrm{Aj}]$ it $[\mathrm{S}]$ meant $[\mathrm{P}]$ there $[\mathrm{S}]$ was $[\mathrm{F}]$ a chance for his friend, Damiete $[\mathrm{C}]$, to pick up the reins Kamal $[\mathrm{S}]$ had $[\mathrm{F}]$ dropped [P].

I $[\mathrm{S}] \operatorname{did}$ not $[\mathrm{Fml} / \mathrm{n}]$ know $[\mathrm{Pml}]$ what $[\mathrm{WH} / \mathrm{C}]$ to do, and $[\mathrm{Aj}] \mathrm{I}[\mathrm{S}]$ needed $[\mathrm{F} / \mathrm{P}]$ someone $[\mathrm{C}]$ to talk to. I $[\mathrm{S}]$ had $[\mathrm{F}]$ failed $[\mathrm{P}]$ in a major way to make $[\mathrm{P}]$ it $[\mathrm{C}] \operatorname{good}[\mathrm{Ca}]$ without losing face $[\mathrm{Ac}]$. Emem $[\mathrm{S}]$ had $[\mathrm{F}]$ been $[\mathrm{P}]$ a good confidant $[\mathrm{Ca}]$ up until $[\mathrm{Aj}]$ that point, but $[\mathrm{Aj}] \mathrm{I}[\mathrm{S}]$ wanted $[\mathrm{F} / \mathrm{P}]$ to share this problem $[\mathrm{C}]$ with Lolo $[\mathrm{C}]$. She $[\mathrm{S}]$ could $[\mathrm{Fml}]$ beat $[\mathrm{Pml}] \mathrm{me}[\mathrm{C}]$ up and $[\mathrm{Aj}]$ still $[\mathrm{Am}]$ comfort $[\mathrm{P}]$ me $[\mathrm{C}]$ with the same hands- the hands of a sister who $[\mathrm{WH} / \mathrm{S}]$ cared $[\mathrm{F} / \mathrm{P}]$ for me $[\mathrm{C}]$. I $[\mathrm{S}]$ did not $[\mathrm{Fml} / \mathrm{n}]$ think $[\mathrm{P}] \mathrm{I}[\mathrm{S}]$ could $[\mathrm{Fml}]$ get $[\mathrm{Pml}]$ the same intimacy $[\mathrm{C}]$ from Emem [C].

When $[\mathrm{WH} / \mathrm{A}] \mathrm{I}[\mathrm{S}]$ was $[\mathrm{F}]$ finally $[\mathrm{Ao}]$ able $[\mathrm{Ca}]$ to talk to Admiral, I $[\mathrm{S}]$ was $[\mathrm{F}]$ almost certain. I $[\mathrm{S}]$ could not $[\mathrm{Fml} / \mathrm{n}]$ explain $[\mathrm{Pml}]$ what $[\mathrm{WH} / \mathrm{S}]$ was $[\mathrm{F}]$ different, $[\mathrm{Ca}]$ but $[\mathrm{Aj}] \mathrm{I}[\mathrm{S}]$ felt $[\mathrm{F} / \mathrm{P}]$ different $[\mathrm{Ca}]$; my insides $[\mathrm{S}]$ felt $[\mathrm{F} / \mathrm{P}]$ different $[\mathrm{Ca}]$. I $[\mathrm{S}]$ was $[\mathrm{F}]$ sitting $[\mathrm{P}]$ on his bed $[\mathrm{Ac}]$, and $[\mathrm{Aj}]$ he $[\mathrm{S}]$ was $[\mathrm{F}]$ reading $[\mathrm{P}]$ some documents $[\mathrm{C}]$ at his desk $[\mathrm{Ac}]$.

"Admiral $[\mathrm{Av}], \mathrm{I}[\mathrm{S}]$ am $[\mathrm{F}]$ pregnant $[\mathrm{Ca}] . "$ The words $[\mathrm{S}]$ rushed out $[\mathrm{F} / \mathrm{P}]$ as though they $[\mathrm{S}]$ would $[\mathrm{Fml}]$ choke $[\mathrm{Pml}] \mathrm{me}[\mathrm{C}]$ if $[\mathrm{Aj}] \mathrm{I}[\mathrm{S}]$ said $[\mathrm{P}]$ them $[\mathrm{C}]$ any slower $[\mathrm{Ac}]$.

He $[\mathrm{S}]$ did not $[\mathrm{Fml} / \mathrm{n}]$ even raise $[\mathrm{Pml}]$ his head $[\mathrm{C}]$ from his paper $[\mathrm{C}]$. "Hmm [At], how do [F] you [S] know $[\mathrm{F} / \mathrm{P}]$ you $[\mathrm{S}]$ are $[\mathrm{F}]$ pregnant $[\mathrm{Ca}]$ ?"

"I [S] just $[\mathrm{Am}]$ know [F/P]," I [S] said [F/P] frustrated [P].

"Have $[\mathrm{F}]$ you $[\mathrm{S}]$ gone $[\mathrm{P}]$ to see $[\mathrm{P}]$ a doctor $[\mathrm{C}]$ ?." He $[\mathrm{S}]$ asked $[\mathrm{F} / \mathrm{P}]$ halfheartedly $[\mathrm{Ac}]$, still $[\mathrm{Am}]$ reading $[\mathrm{P}]$ his paper [C].

"No $[\mathrm{Ap}]$, but $[\mathrm{Aj}] \mathrm{I}[\mathrm{S}]$ know $[\mathrm{F} / \mathrm{P}] \mathrm{I}[\mathrm{S}]$ am $[\mathrm{F}]$ pregnant $[\mathrm{Ca}]$. ." The tone of my voice $[\mathrm{S}]$ was $[\mathrm{F}]$ rising $[\mathrm{P}]$ [[exposing $[\mathrm{P}]$ my exasperation $[\mathrm{C}]]][[\mathrm{Ac}]$.

I $[\mathrm{S}]$ stood up $[\mathrm{F} / \mathrm{P}]$ and $[\mathrm{Aj}]$ went $[\mathrm{F} / \mathrm{P}][$ [to put my hands on his shoulders]] [Ac]. "Admiral [Av], are $[\mathrm{F}]$ you $[\mathrm{S}]$ even listening $[\mathrm{P}]$ to me $[C]$ ?"

He $[\mathrm{S}]$ stopped $[\mathrm{F} / \mathrm{P}]$ reading and $[\mathrm{Aj}]$ sat $[\mathrm{P}]$ me $[\mathrm{C}]$ on his lap $[\mathrm{Ac}]$. "I $[\mathrm{S}]$ heard $[\mathrm{F} / \mathrm{P}]$ you $[\mathrm{C}]$. You $[\mathrm{S}]$ say $[\mathrm{F} / \mathrm{P}]$ you $[\mathrm{S}]$ are $[\mathrm{F}]$ pregnant $[\mathrm{Ca}]$, not so?"

"Yes [Ap], so $[\mathrm{Aj}]$ what $[\mathrm{WH} / \mathrm{C}]$ am $[\mathrm{F}] \mathrm{I}[\mathrm{S}]$ going to do $[\mathrm{P}]$ ?"

"Well [At], first $[\mathrm{Aj}]$ you $[\mathrm{S}]$ have to $[\mathrm{Fml}]$ confirm $[\mathrm{Pml}]$ that you $[\mathrm{S}]$ are $[\mathrm{F}]$ pregnant $[\mathrm{Ca}]$, and $[\mathrm{Aj}]$ only $[\mathrm{Am}]$ a doctor $[\mathrm{S}]$ can $[\mathrm{Fml}]$ do $[\mathrm{Pml}]$ that $[\mathrm{C}]$. And $[\mathrm{Aj}]$ if $[\mathrm{Aj}]$ you $[\mathrm{S}]$ are $[\mathrm{F}]$ pregnant $[\mathrm{Ca}], \mathrm{I}[\mathrm{S}]$ have $[\mathrm{F}]$ a friend who $[\mathrm{WH} / \mathrm{S}]$ can $[\mathrm{Fml}]$ take care of $[\mathrm{Pml}]$ it $[\mathrm{C}]$."

Then $[\mathrm{Aj}]$ with the same absent-mindedness with which $[\mathrm{WH} / \mathrm{C}]$ he $[\mathrm{S}]$ had $[\mathrm{F}]$ been listening $[\mathrm{P}]$ to me $[\mathrm{C}]$, he $[\mathrm{S}]$ said $[\mathrm{F} / \mathrm{P}]$, "Please let me [S] finish [P] this $[\mathrm{C}]$ and $[\mathrm{Aj}]$ we $[\mathrm{S}]$ can [Fml] talk [Pml], okay [At]?"

I $[\mathrm{S}]$ had $[\mathrm{F}]$ expected $[\mathrm{P}]$ a warmer response $[\mathrm{C}]$ from him $[\mathrm{C}]$. Instead, he $[\mathrm{S}]$ was $[\mathrm{F}]$ cold and distant $[\mathrm{Ca}]$, like he $[\mathrm{S}] \operatorname{did}$ not $[\mathrm{Fml} / \mathrm{n}]$ care $[\mathrm{Pml}]$. I $[\mathrm{S}]$ felt $[\mathrm{F} / \mathrm{P}]$ as if $[\mathrm{Aj}] \mathrm{I}[\mathrm{S}]$ had $[\mathrm{F}]$ been gutted $[\mathrm{P}]$, and $[\mathrm{Aj}]$ for the first time since I $[\mathrm{S}]$ suspected $[\mathrm{F} / \mathrm{P}]$ the pregnancy $[\mathrm{C}]$, I $[\mathrm{S}]$ felt $[\mathrm{F} / \mathrm{P}]$ the urge to vomit $[\mathrm{Ca}]$. I $[\mathrm{S}]$ quickly $[\mathrm{Ac}]$ packed up $[\mathrm{F} / \mathrm{P}]$ my things $[\mathrm{C}]$, forced out $[\mathrm{F} / \mathrm{P}]$ a good-bye to Admiral $[\mathrm{C}]$, and $[\mathrm{Aj}]$ dashed $[\mathrm{F} / \mathrm{P}]$ out of his house $[\mathrm{Ac}]$. He [S] barely $[\mathrm{Am}]$ looked $[\mathrm{F} / \mathrm{P}]$ up to say $[\mathrm{P}]$ good-bye.

A few days later $[\mathrm{Ac}]$, Sisi's security guard $[\mathrm{S}]$ called $[\mathrm{F} / \mathrm{P}]$ me $[\mathrm{C}]$ late in the night $[\mathrm{Ac}]$. It $[\mathrm{S}]$ was $[\mathrm{F}]$ Admiral $[\mathrm{C}]$ waiting $[\mathrm{P}]$ for $\mathrm{me}[\mathrm{C}]$ outside the gate $[\mathrm{Ac}]$. It $[\mathrm{S}]$ had $[\mathrm{F}]$ become $[\mathrm{P}]$ common practice $[\mathrm{C}]$ for the security man to call $[\mathrm{P}]$ me $[\mathrm{C}]$ out at night $[\mathrm{Ac}]$ to see $[\mathrm{P}]$ Admiral or his driver $[\mathrm{C}]$; because $[\mathrm{Aj}] \mathrm{I}[\mathrm{S}]$ rewarded $[\mathrm{F} / \mathrm{P}]$ him $[\mathrm{C}]$ handsomely $[\mathrm{Ac}]$, he $[\mathrm{S}]$ did $[\mathrm{Fml}] \mathrm{me}[\mathrm{C}]$ the favour of announcing their presence $[\mathrm{C}]$ with the utmost discretion $[\mathrm{C}]$. Esther $[\mathrm{S}]$ also $[\mathrm{Aj}]$ got $[\mathrm{P}]$ her rewards $[\mathrm{C}]$ for zipping her lips about my late-night escapades 
$[\mathrm{Ac}]$. Although $[\mathrm{Aj}]$ she $[\mathrm{S}]$ rarely $[\mathrm{Am}]$ accepted $[\mathrm{F} / \mathrm{P}]$ cash $[\mathrm{C}]$ from me $[\mathrm{C}]$, she $[\mathrm{S}]$ accepted $[\mathrm{F} / \mathrm{P}]$ the little gifts that $\mathrm{I}[\mathrm{S}]$ got $[\mathrm{F} / \mathrm{P}]$ for her when $[\mathrm{WH} / \mathrm{A}] \mathrm{I}[\mathrm{S}]$ went $[\mathrm{F} / \mathrm{P}]$ to the market $[\mathrm{Ac}]$.

"Why [WH/A] did [Fml] you [S] run off [Pml] the other day $[\mathrm{Ac}]$ ?"

"I [S] didn't [Fml/n] run off [Pml]. You [S] were [F] busy, so [Aj] I [S] left, [F/P]" I [S] hissed. [F/P]

"So $[\mathrm{Aj}]$ have $[\mathrm{F}]$ you $[\mathrm{S}]$ gone $[\mathrm{P}]$ to see a doctor?" [C]

"No, [Ap] but [Aj] I'[S] 11 [Fml] go [Pml] this week," I [S] said [F/P] hurriedly. [Ao]

"Well $[\mathrm{At}]$, take $[\mathrm{P}]$ this $[\mathrm{C}]$, , he $[\mathrm{S}]$ said, $[\mathrm{F} / \mathrm{P}]$ and $[\mathrm{Aj}]$ handed $[\mathrm{F} / \mathrm{P}]$ me $[\mathrm{C}]$ an envelope full of money $[\mathrm{C}]$.

"Go [P] to Island Clinic $[\mathrm{Ac}]$ and $[\mathrm{Aj}]$ ask $[\mathrm{P}]$ for Dr. George $[\mathrm{C}]$. Tell $[\mathrm{P}]$ him $[\mathrm{C}]$ you $[\mathrm{S}]$ need $[\mathrm{Fml}]$ a pregnancy test $[\mathrm{C}$,$] and [\mathrm{Aj}]$ if $[\mathrm{Aj}]$ you $[\mathrm{S}]$ are $[\mathrm{F}]$ pregnant $[\mathrm{Ca}]$, he $[\mathrm{S}]$ will $[\mathrm{Fml}]$ help $[\mathrm{Pml}]$ you $[\mathrm{C}]$ get rid $[\mathrm{P}]$ of it [C].

$\mathrm{I}[\mathrm{S}]$ looked $[\mathrm{F} / \mathrm{P}]$ at him $[\mathrm{C}]$, and $[\mathrm{Aj}] \mathrm{I}[\mathrm{S}]$ could not $[\mathrm{Fml} / \mathrm{n}]$ find $[\mathrm{Pml}]$ any softness $[\mathrm{C}]$ in his face $[\mathrm{Ac}]$. His boyish countenance with the dimples $[\mathrm{S}]$ looked $[\mathrm{F} / \mathrm{P}]$ more like frightening apparition $[\mathrm{Ca}]$. I $[\mathrm{S}]$ almost choked $[\mathrm{F} / \mathrm{P}]$ on a scream $[\mathrm{Ac}]$ as I $[\mathrm{S}]$ tried $[\mathrm{F} / \mathrm{P}]$ to smother $[\mathrm{P}]$ it $[\mathrm{C}]$. Since $[\mathrm{Aj}] \mathrm{I}[\mathrm{S}]$ could not $[\mathrm{Fml} / \mathrm{n}]$ shout $[\mathrm{Pml}]$, I $[\mathrm{S}]$ wanted $[\mathrm{F} / \mathrm{P}]$ to at least smash $[\mathrm{P}]$ all the windows in his car $[\mathrm{C}]$. I $[\mathrm{S}]$ was $[\mathrm{F}]$ allowed $[\mathrm{Pml}]$ to tantrum $[\mathrm{P}]$ for his callousness $[\mathrm{C}]$. There $[\mathrm{S}]$ was $[\mathrm{F}]$ no room for a discussion $[\mathrm{Ca}]$. He $[\mathrm{S}] \operatorname{did}$ not $[\mathrm{Fml} / \mathrm{n}]$ ask $[\mathrm{Pml}]$ whether I $[\mathrm{S}]$ wanted $[\mathrm{F} / \mathrm{P}]$ to keep $[\mathrm{P}]$ the child $[\mathrm{C}]$ or not. He $[\mathrm{S}]$ did not $[\mathrm{Fml} / \mathrm{n}]$ care, $[\mathrm{Pml}]$ and $[\mathrm{Aj}]$ if $[\mathrm{Aj}] \mathrm{I}$ $[\mathrm{S}]$ kept $[\mathrm{P}]$ the baby $[\mathrm{C}]$, I [S] was [F] definitely $[\mathrm{Am}]$ on my own [Ca]. Sisi [S] would [Fml] undoubtedly [Ao] send $[\mathrm{Pml}]$ me $[\mathrm{C}]$ packing $[\mathrm{C}]$. She $[\mathrm{S}]$ had $[\mathrm{F}]$ signed on $[\mathrm{P}]$ to help enable $[\mathrm{P}]$ me $[\mathrm{C}]$ to further my education $[\mathrm{C}]$, not start $[\mathrm{P}]$ a family $[\mathrm{C}]$.

$\mathrm{I}[\mathrm{S}]$ was $[\mathrm{F}]$ jolted $[\mathrm{P}]$ into reality $[\mathrm{C}]$. Admiral $[\mathrm{S}]$ did not $[\mathrm{Fml} / \mathrm{n}]$ have $[\mathrm{Pml}]$ the time $[\mathrm{C}]$ to commit $[\mathrm{P}]$ to me $[\mathrm{C}]$, and $[\mathrm{Aj}][[$ expecting $[\mathrm{P}]$ anything more $[\mathrm{C}]$ from him $[\mathrm{C}]]]$ was $[\mathrm{F}]$ stupid $[\mathrm{Ca}]$. In my romanticised view of Admiral $[\mathrm{Ac}]$, he $[\mathrm{S}]$ would not $[\mathrm{Fml} / \mathrm{n}]$ hold $[\mathrm{Pml}]$ me $[\mathrm{C}]$, tell $[\mathrm{Pml}]$ me $[\mathrm{C}]$ he $[\mathrm{S}]$ could not $[\mathrm{Fml} / \mathrm{n}]$ wait $[\mathrm{Pml}]$ to receive $[\mathrm{P}]$ the product of our love $[\mathrm{C}]$, and $[\mathrm{Aj}]$ even $[\mathrm{Am}]$ propose $[\mathrm{P}][[$ to marry me]] $[\mathrm{C}]$. Why not? $[\mathrm{WH} / \mathrm{A}]$ There $[\mathrm{S}]$ were $[\mathrm{F}]$ tons of older men $[\mathrm{C}]$ who $[\mathrm{WH} / \mathrm{S}]$ had $[\mathrm{F}]$ married $[\mathrm{P}]$ young girls $[\mathrm{C}]$ who $[\mathrm{WH} / \mathrm{S}]$ found $[\mathrm{F} / \mathrm{P}]$ a balance $[\mathrm{C}]$ between having $[\mathrm{F}]$ their babies $[\mathrm{C}]$ with studying for their final exams $[\mathrm{Ac}]$ and $[\mathrm{Aj}]$ eventually $[\mathrm{Am}]$ writing their thesis $[\mathrm{C}]$ for doctorate degrees $[\mathrm{Ac}]$. Even if $[\mathrm{Aj}]$ he $[\mathrm{S}] \operatorname{did}$ not $[\mathrm{Fml} / \mathrm{n}]$ propose $[\mathrm{Pml}]$, he $[\mathrm{S}]$ would $[\mathrm{Fml}]$ give $[\mathrm{Pml}]$ me $[\mathrm{C}]$ assurances $[\mathrm{C}]$ that there $[\mathrm{S}]$ was $[\mathrm{F}]$ no need to panic $[\mathrm{Pml}]$ because $[\mathrm{Aj}]$ he $[\mathrm{S}]$ would $[\mathrm{Fml}]$ take care $[\mathrm{Pml}]$ of me $[\mathrm{C}]$. I $[\mathrm{S}]$ expected $[\mathrm{P}]$ that a man of his age, with his comforts, would [Fml] welcome [Pml] the news of fathering a child [C]. But [Aj] I [S] should [Fml] have known $[\mathrm{Pml}]$ better $[\mathrm{Ac}]$, and $[\mathrm{Aj}] \mathrm{I}[\mathrm{S}]$ had $[\mathrm{F}]$ no one $[\mathrm{C}]$ to blame $[\mathrm{P}]$ but $[\mathrm{Aj}]$ myself $[\mathrm{C}]$ since $[\mathrm{Aj}]$ his reputation with young girls $[\mathrm{S}]$ far, far $[\mathrm{Am}]$, preceded $[\mathrm{F} / \mathrm{P}]$ him $[\mathrm{C}]$.

Dr. George $[\mathrm{S}]$ was $[\mathrm{F}]$ out of the question $[\mathrm{Ca}]$. He $[\mathrm{S}]$ had to $[\mathrm{Fms}]$ be $[\mathrm{Pms}]$ /the doctor $[\mathrm{C}]$ who $[\mathrm{WH} / \mathrm{C}]$ rich men $[\mathrm{S}]$ sent $[\mathrm{F} / \mathrm{P}]$ their girlfriends $[\mathrm{C}]$ to for abortion $[\mathrm{Ac}]].[\mathrm{C}]$ Admiral $[\mathrm{S}]$ had $[\mathrm{F}]$ probably $[\mathrm{Am}]$ sent $[\mathrm{P}]$ dozens of girls[C] to him [C]. I [S] could not [Fml/n] bear [Pml] the shame of being seen as one of the poor little girls $[\mathrm{C}]$ taken advantage of $[\mathrm{P}]$ by her sugar daddy. Admiral [S] would [Fml] have discussed [Pml] the situation $[\mathrm{C}]$ with Dr. George $[\mathrm{C}]$, and $[\mathrm{Aj}]$ one indiscreet nurse $[\mathrm{S}]$ meant $[\mathrm{F} / \mathrm{P}]$ that my story would $[\mathrm{Fms}]$ be $[\mathrm{Pms}]$ all over town $[\mathrm{Ca}]$. I [S] could not $[\mathrm{Fml} / \mathrm{n}]$ risk $[\mathrm{Pml}]$ that $[\mathrm{C}]$.

A pregnancy test kit from the pharmacy $[\mathrm{S}]$ confirmed $[\mathrm{F} / \mathrm{P}]$ that $\mathrm{I}[\mathrm{S}]$ was $[\mathrm{F}]$ pregnant $[\mathrm{Ca}]$, and $[\mathrm{Aj}]$ then $[\mathrm{Aj}]$ another reality $[\mathrm{S}]$ surfaced-[F/P] there $[\mathrm{S}]$ was $[\mathrm{F}]$ a possibility that the seed growing in my stomach $[\mathrm{S}]$ was not $[\mathrm{Fn}]$ planted [P] by Admiral [Ac].

\subsection{Summarized Findings Data}

As the mood analysis in this extract exudes, the analysis revealed that:

$>$ the extract contains 176 moods unevenly distributed among the major four mood types identified as follows; 161 (i.e., 91.47\%) declaratives, 02 (i.e., $01.13 \%$ ) imperatives, 11 (i.e., $06.25 \%$ ) interrogative and 02 (i.e., $01.13 \%$ ) modulated interrogative.

$>$ the extract under study contains 84 modalities disaggregated into 14 (i.e., 16.66\%) epistemic modality and 70 (i.e., $83.33 \%$ ) deontic modality.

The salient findings revealed by the interpersonal meaning analysis, namely: epistemic and deontic modality and mood items are counted, disaggregated, summarized and reported in the Tables $2 \& 3$ below. 
Table 2. Summary of mood and modality patterns in the extract

\begin{tabular}{|c|c|c|c|c|c|}
\hline \multirow{2}{*}{$\begin{array}{l}\text { No } \\
1\end{array}$} & \multicolumn{5}{|c|}{ Mood Properties in the Inaugural Speech } \\
\hline & Mood Types & Declaratives & Interrogatives & $\begin{array}{l}\text { Modulated } \\
\text { Interrogatives }\end{array}$ & Imperatives \\
\hline & Frequency $^{176}$ & 161 & 11 & 02 & 02 \\
\hline & Percentage & $91.47 \%$ & $06.25 \%$ & $01.13 \%$ & $01.13 \%$ \\
\hline \multirow[t]{3}{*}{2} & Modality Types & Epistemic $(M$ & zation) & & Deontic (Modulation) \\
\hline & Frequency $^{84}$ & 14 & & & 70 \\
\hline & Percentage & $16.66 \%$ & & & $83.33 \%$ \\
\hline
\end{tabular}

Table 3. Modal auxiliaries in the extract along with their level of commitment

\begin{tabular}{lllll}
\hline \multirow{2}{*}{ No } & POLARITY & \multicolumn{3}{c}{ MODALITY LEVEL } \\
\cline { 3 - 5 } & & Low & Median & High \\
\hline 1 & Positive & Can, may, could, might & Will, would, shall & Must, have/had to, need \\
2 & Negative & $\begin{array}{l}\text { Doesn't/didn't, cannot, } \\
\text { could not }\end{array}$ & $\begin{array}{l}\text { Won't, would not, } \\
\text { should not }\end{array}$ & Mustn't, couldn't \\
\hline
\end{tabular}

\section{Critical Discussion of the Findings}

As the analysis exudes, there is a systematic asymmetric distribution of the 176 mood types used in the extract under study between declarative, interrogative, modulated interrogative and imperative moods. The preponderant presence of 161 (i.e., 91.47\%) declaratives is indicative of an information-centered discourse/text. Moreover, this establishes a distant relationship between old Sisi (the tutor) and Zilayefa the adopted and accommodated daughter. This distance that is created as a result of the circumstances and age difference between the two participants, on the one hand, and equally exists between Lolo (younger than Sisi) and Zilayefa, on the other. Sisi appeared in position of higher authority. Indeed, it is this kind of distance authority that is established and maintained in education sector between the teacher and learner, though it is sometimes modulated to enable the conveyed messages pass across. Lolo clearly performed this mother-to-daughter authority through some of her interrogations and imperative mood directed to Zilayefa when she became scarce at home even during her off-times at work.

1- "What is your boyfriend's name?

2- "Don't lie to me.

3- "What is your boyfriend's name?

4- "Don't pass and you will see what I will do to you.

This distance created and maintained through authority-in-second of Lolo is indicative and expressive of the ambition that these two women nurture for Zilayefa who, to some extent, was unaware of the deep sense of women life. But based on their past men-to-women relational experiences, Sisi and Lolo rather did not want Zilayefa to fall in the same social snares that had affected and wounded their heart. Instead, they struggle to secure a brilliant and bright future for their "daughter".

They are fully aware of the open and clandestine prostitution spread in an oil mining town like Port Harcourt where young girls easily fall in the traps of some sugar daddies or white men working for oil companies or sailing. For instance, Zilayefa's mother was impregnated by a Greek sailor who departed for ever without a simple farewell to her. That pregnancy gave birth to Zilayefa; hence she, the fruit of such lost relationship is a target of social discrimination and stigma. People had preconceived notions about mixed race girls: they are regarded as conceited, promiscuous, undisciplined, born-troways, products of women of easy virtue.

The Port Harcourt tutors' objective is that Zilayefa should not fall in the same wrong path like her mother. Obviously, the objective pursued by Sisi and Lolo is to ensure a community-based girl protection and education for Zilayefa as that would prevent her from facing and suffering from social and professional oppression in future. This women's sustained determination to foster girls' emancipation and empowerment through Zilayefa's education and social welfare is, above all and beyond the person of Zilayefa, the expression and materialization of the community-based developmental strategy through Agary's intra-gender emancipatory discourse. This kind of emancipatory discourse is much more needed nowadays to foster girls' education. And this could effectively help African society establish a balance and kill the germs of ignorance. Of course, by being qualified, capacitated and able to sit around the same policy and decision-making table with men for human, women can significantly 
take the lead and influence some crucial actions for the advancement of the society. It can be, therefore, inferred that Sisi and Lolo's unflinching support comes to deny the sociocultural impediments and constraints coercingly relegating and placing African women and girls behind the burning firewood, the cooking pot, and ultimately in the bedroom (Koussouhon \& Dossoumou, 2015).

The one going against the women's stream flow is the male character impersonated in Admiral. By minimizing social distance between Zilayefa and himself through the use of some few interrogative and modulated interrogative mood patterns, Admiral brought no positive contribution to the societal fulfillment of Zilayefa. Rather, he strongly influenced and spoiled her with money power and eventually, impregnated and jilted her down. It is certainly on purpose of achieving his objective that Admiral established a face-to-face power discourse situation in an unequal encounter between him and naïve Zilayefa. The modulated interrogative mood along with some deontic modality choices revealed, in the end, the other side of the medal painted and depicted in the fiction through the character of Admiral.

5- I expected that a man of his age, with his comforts, would welcome the news of fathering a child;

6- then we'll worry about the rest

7- I could not explain what was different

8- He did not even raise his head from his paper

9- first you have to confirm that you are pregnant

10- I have a friend who can take care of it

11- let me finish this and we can talk, okay?

12- I could not find any softness in his face

In the above stated eight (08) clauses in relation to Admiral's reaction on hearing about the pregnancy he authored, only two of the modalities are median (will, and would), one high (have to) two positively-low (can), and three highly-negative (could not and did not). Auxiliary "will" performs two mains functions in the discourse/speech/text. First and foremost, it is used to express future actions to be taken or carried out. Admiral has just used it to engulf the whole attention of the young girl and embark her onto a futureless venture. Admiral, in his move to deconstruct male characters, also used "will" as a modal verbal operator assumed to illustrate his strong wish and desire to continue developing a relation of candor with Zilayefa. Instead, he used will operator devoided of any practical function and degree of certainty. The avoidance of the second median modal operator is "would" by Admiral is a sign announcing his forthcoming dodging and lack of responsibility and accountability in his relationship with the girl; unfortunately the poor and naïve girl did not understand the deep meaning behind her partner's discourse.

Regarding the high degree modality, it has been used five times in the extract as illustrated in the clauses reported below:

13- Whatever spirit $\underline{I \text { had to }}$ thank for all my luck;

14- I believe it had to be a female spirit with a mother's compassion;

15- And for that I had to be very careful not to offend her;

16- Well, first you have to confirm that you are pregnant;

17- He had to be the doctor whom rich men sent their girlfriends to for abortion;

The first three clauses $(13 ; 14 ; \& 15)$ containing the high scale modal ( "had to"). At this level it is indicative of full commitment. It refers to the female spirit behind Zilayefa's luck and success; that spirit is believed to support her with a mother's compassion. Obviously, the choice of this modal to express female's accountability and commitment to a girl is deliberate and bears up the preponderant use of declarative mood discussed in earlier paragraphs.

The last two high scale modal clauses (16 \& 17) strongly go against the normal order of characters' commitment. Clause (16) adamantly rejects the entire responsibility of confirmation of pregnancy on the girl. Clause (17) entirely recognized "He" (referring to Doctor George) as the participant character in charge of performing the dirty job and possessing the most famous abortive clinic in Port Harcourt. These last two high scale modal auxiliaries equally add more emphasis and impetus on the poor role performed by some rich men referred to as "sugar daddies" in Nigeria and, to a large extent, in Africa as a whole. 
By and large, the discussion of the salient properties of the grammar of interpersonal meaning encoded in Kaine Agary's fiction has contributed to shed more light on the hidden aspects of her text/discourse. The mood and modality choices operated and used in the extract are significant regarding the re-establishment of the gender-balanced social relationships in Africa. More importantly, the use of the deontic and epistemic modality have contributed to enlightening more the ideology and values sustaining Kaine Agary's fiction, the end-purpose of which is to foster a sustainable community-based protection, education, commitment and accountability by/for women's social and societal advancement. It can be inferred that Agary's novel is a women-centered oeuvre. In line with Layli (2006) this extract rejects any kind of oppression against women. It is communitarian because women community has struggled hand in glove to ensure a girl' success both at school and in the society at large. That unflinching support of women to women's cause has even been presumably sustained by an alleged female spirit. Women's support to the young girl considered neither her village origin nor her social class; it was just vernacular. All these fictional realities in the extract and in the novel at large confirm the womanist theory championed by some scholars.

\section{Conclusion}

This paper has applied the grammar of interpersonal meaning to Kaine Agary' Yellow-Yellow (2006). The linguistic description has revealed all the hidden mood and modality patterns enshrined therein. The finding data have been collected, screened, disaggregated and summarized in two distinct tables ( $2 \& 3)$ making them easily readable and understandable. The critical discussion of the monological and dialogical fiction under study unearthed the power relations as established and portrayed in the novel. The authoritarian, tutorial and/or mother-to-daughter relations between Sisi, Lolo and Zilayefa on the one hand, and, the imbalanced money power which influenced and tailored the relations between Admiral and Zilayefa, on the other, until the latter became pregnant, have been profusely illustrated in the passage.

The discussion of the findings across the womanist theory lens culminated with some crucial topical issues and priorities of African society. These are the ones expected to foster a sustainable community-based protection, education, commitment and accountability for women's social and societal advancement.

In a nutshell, this paper contends with Layli (2006) that Kaine Agary, through her novel has rejected any kind of oppression against women. Besides, the passage has portrayed how women pooled effort and struggled together in order to ensure a girl's success both at school and in the society at large. The interpretation of the data has revealed that the unflinching support willingly availed by women to the cause of their peer has even been presumably sustained by an alleged female spirit. The discussion came up with the conclusion that the support that the young girl enjoyed considered neither her village origin nor her social class; it was just vernacular (Layli, 2006).

Eventually, this paper has been premised on a challenging but essential need. It has to do with trying to combine the grammar of interpersonal meaning and critical discussion in order to reach an agreement. This agreement is that the hidden authorial ideology behind Kaine Agary's fictional text is geared towards a pro-women social change for a more balanced African society. This is, of course, the gist priorities and great topical issues calling for urgent response at this time. Indeed, reaching this agreement is sufficient and essential for the sake of, and the focus it gives this research paper. However, any further continuing disagreement with the thinking ventured in this research paper would be encouraged in order to avoid any exclusive deadening orthodoxy.

\section{References}

Agary, K. (2006). Yellow-Yellow (1st ed.). Sabo, Yaba, Lagos: Dtalkshop.

Akogbeto, P., \& Koukpossi, A. (2015). Gender Issues in the Lion and the Jewel by Wole Soyinka: A Linguistics-Oriented Analysis from a Systemic Functional Grammar and Critical Discourse Analysis Perspective. Communication and Linguistics Studies, 1(2), 26-34.

Ali, S., \& Kazemian, B. (2015). Critical Discourse Analysis of a Reading Text 'Pakistan and the Modern World': A Speech by Liaquat Ali Khan. Communication and Linguistics Studies, 1(3), 35-41.

Ali, S., Kazemian, B., \& Bughio, F. A. (2015). An investigation of the reading text 'Pakistan Zindabad' (Long Live Pakistan): Critical discourse analysis perspective. Education and Linguistics Research, 1(2), 42-51. http://dx.doi.org/10.5296/10.5296/elr.v1i2.8160

Amoussou, Y. C. (2015). Mood, Interpersonal and Ideological Meaning Patterns in the Abiku poems (J.P. Clark; W. Soyinka). International Journal of Language and Linguistics, 2(3). 
Ayoola, M. (2013). Interpersonal and Ideational Metafunctions of Some Selected Political Advertisements in Some Nigerian Newspapers. International Journal of Humanities and Social Science, 3(8), 165-178.

Cap, P., \& Okulska, U. (Eds.). (2013). Analyzing genres in political communication: theory and practice (Vol. 50). John Benjamins Publishing. http://dx.doi.org/10.1075/dapsac.50

Carter, R. A., \& Simpson, P. W. (2005). Language, Discourse and Literature: An Introductory Reader in Discourse Stylistics (2nd ed.). USA and Canada: Routledge.

Eggins, S. (2004). An Introduction to Systemic Functional Linguistics (2nd ed.). Manchester, Great Britain: Continuum.

Fairclough, I., \& Fairclough, N. (2012). Political Discourse Analysis: A Method for Advanced Students. London and New York: Routledge.

Fairclough, N. (2003). Analysing Discourse: Textual analysis for social research. London and New York: Routledge.

Fairclough, N. (2015). Language and Power (3rd ed.). London and New York: Routledge.

Fontaine, L. (2013). Analysing English Grammar: A Systemic Functional Introduction. New York: Cambridge University Press.

Fowler. (1986). Linguistic Criticism. London: Oxford University Press.

Gledhill, Ch. (2011). The 'lexicogrammar' approach to analyzing phraseology and Collocation. Asp, (59), 5-23. http://dx.doi.org/10.4000/asp.2169

Halliday, M. A. K (2009). Language and Society. London - New York: Continuum.

Halliday, M. A. K. (1971). Linguistic function and literary style: An inquiry into the language of William Golding's The Inheritors. In S. B. Chatman (Ed.), Literary Style. London and New York: Oxford University Press.

Halliday, M. A. K., \& Hasan, R. (1985). Language, context and text: aspect of language in a social- semiotic perspective. Oxford: Oxford University Press.

Halliday, M. A. K., \& Matthiessen, Ch. (2004). An Introduction to Functional Grammar (3rd ed.). London: Hodder Education, and Hachette UK Company.

Halliday, M. A. K., \& Matthiessen, Ch. (2006). Construing Experience through Meaning: A Language-based Approach to Cognition. London - New York: Continuum.

Hasan, R., \& Webster, J. J. (2005). Language, Society and Consciousness: The Collected Works of Ruqaiya Hasan Volume 1. London: Equinox Publishing Ltd.

Houghton, M. (1993). American Heritage College Dictionary 3rd Indexed Edition. USA: Houghton Mifflin (T).

Kazemian, B., \& Hashemi, S. (2014a). Nominalizations in scientific and political genres: A systemic functional linguistics perspective. International Journal of Humanities and Social Sciences, 3(2), 211-228.

Kazemian, B., \& Hashemi, S. (2014b). Critical discourse analysis of Barack Obama's 2012 speeches: Views from systemic functional linguistics and rhetoric. Theory and Practice in Language Studies, 4(6), 1178-1187. http://dx.doi.org/10.4304/tpls.4.6.1178-1187

Kazemian, B., Behnam, B., \& Ghafoori, N. (2013). Ideational grammatical metaphor in scientific texts: a Hallidayan perspective. International Journal of Linguistics, 4(4), 146-168. http://dx.doi.org/10.5296/ijl.v5i4.4192

Koussouhon, L., \& Allagbe, A. (2013). The Lexico-grammar of Chimamanda Ngozi Adichie' fiction: A systemic functional contribution. Langage \& Devenir, (22), 19-44.

Koussouhon, L., \& Dossoumou, A. (2014). Lexico-grammatical Analysis of Yellow-Yellow by Kaine Agary: Focus on Experiential and Textual Meanings. Mediterranean Journal of Social Sciences, 5(23), 2430-2438. http://dx.doi.org/10.5901/mjss.2014.v5n23p2430

Koussouhon, L., \& Dossoumou, A. (2015). Exploring Ideational Metafunction in Helon Habila's Oil on Water: A re-evaluation and redefinition of African Women's Personality and Identity through Literature. International Journal of Applied Linguistics \& English Literature, 4(5), 129-136.

Koussouhon, L., \& Koukpossi, A. (2013). Analyze lexico-grammaticale du discours d'investiture de François Hollande avec un accent spécial sur la transitivité. Revue Togolaise des Sciences, 7(1), 353-372. 
Layli, Ph. (2006). The Womanist Reader. London and New York: Routledge.

Noor, M., Ali, M., Muhabat, F., \& Kazemian, B. (2015a). Systemic Functional Linguistics Mood Analysis of the Last Address of the Holy Prophet (PBUH). International Journal of Language and Linguistics, 4(1-1), 1-9. http://dx.doi.org/10.11648/j.ijll.s.2015030501.11

Noor, M., Mustafa, R., Muhabat, F., \& Kazemian, B. (2015b). The Language of TV Commercials' Slogans: A Semantic Analysis. Communication and Linguistics Studies, 1(1), 7-12. http://dx.doi.org/10.11648/j.cls.20150101.12

Nørgaard, N. et al. (2010). Key Terms in Stylistics. London and New York: Continuum.

Nur, S. (2015). Analysis of interpersonal metafunction in public speeches: a case study of nelson mandela's presidential inauguration speech. The International Journal of Social Sciences, 30(1), 52-63.

Simpson, P. (1994). Stylistics: a Resource Book for Students. London: Routledge.

Taiwo, O. (2014). A Critical Discourse Analysis of Modals in Nigerian Political Manifestos. International Journal of Linguistics, 6(3), 109-117. http://dx.doi.org/10.5296/ijl.v6i3.5589

Tyson, L. (2006). Critical Theory Today: A User-Friendly Guide (2nd ed.). New York and London: Routledge.

Van Leeuwen. (2006). Critical discourse analysis. In K. Brown (Ed.), Encyclopedia of Language and Linguistics. Amsterdam: Elsevier Science.

Wodak, R. (2011). The Discourse of Politics in Action: Politics as Usual. London and New York: Palgrave Macmillan. http://dx.doi.org/10.1057/9780230316539

Ye, R. (2010). The Interpersonal Metafunction Analysis of Barack Obama's Victory Speech. English Language Teaching, 3(2), 146-151. http://dx.doi.org/10.5539/elt.v3n2p146

Young, L., \& Harrison, C. (2004). Systemic Functional Linguistics and Critical Discourse Analysis, studies in social change. London and New York: Continuum.

Zhou, Q., \& Kazemian, B. (2015). A Rhetorical Identification Analysis of English Political Public Speaking: John F. Kennedy's Inaugural Address. International Journal of Language and Linguistics. Special Issue: Critical Discourse Analysis, Rhetoric, and Grammatical Metaphor in Political and Advertisement Discourses, 4(1-1), 10-16. http://dx.doi.org/10.11648/j.ijll.s.2016040101.12

\section{Copyrights}

Copyright for this article is retained by the author(s), with first publication rights granted to the journal.

This is an open-access article distributed under the terms and conditions of the Creative Commons Attribution license (http://creativecommons.org/licenses/by/3.0/). 